University of Nebraska - Lincoln

DigitalCommons@University of Nebraska - Lincoln

\title{
Site-Specific Management Zones Based on Soil Electrical Conductivity in a Semiarid Cropping System
}

Cinthia K. Johnson

USDA-ARS, cjohnso2@bigred.unl.edu

David A. Mortensen

Pennsylvania State University

Brian J. Wienhold

University of Nebraska-Lincoln, Brian.Wienhold@ars.usda.gov

J.F. Shanahan

University of Nebraska-Lincoln, jshanahan1@unl.edu

John Doran

University of Nebraska-Lincoln, jdoran1@unl.edu

Follow this and additional works at: https://digitalcommons.unl.edu/usdaarsfacpub

Johnson, Cinthia K.; Mortensen, David A.; Wienhold, Brian J.; Shanahan, J.F.; and Doran, John, "SiteSpecific Management Zones Based on Soil Electrical Conductivity in a Semiarid Cropping System" (2003). Publications from USDA-ARS / UNL Faculty. 1184.

https://digitalcommons.unl.edu/usdaarsfacpub/1184

This Article is brought to you for free and open access by the U.S. Department of Agriculture: Agricultural Research Service, Lincoln, Nebraska at DigitalCommons@University of Nebraska - Lincoln. It has been accepted for inclusion in Publications from USDA-ARS / UNL Faculty by an authorized administrator of DigitalCommons@University of Nebraska - Lincoln. 


\title{
SITE-SPECIFIC MANAGEMENT
}

\section{Site-Specific Management Zones Based on Soil Electrical Conductivity in a Semiarid Cropping System}

\author{
Cinthia K. Johnson, * David A. Mortensen, Brian J. Wienhold, John F. Shanahan, and John W. Doran
}

\begin{abstract}
Site-specific management (SSM) can potentially improve both economic and ecological outcomes in agriculture. Effective SSM requires strong and temporally consistent relationships among identified management zones; underlying soil physical, chemical, and biological parameters; and crop yields. In the central Great Plains, a 250-ha dryland experiment was mapped for apparent electrical conductivity $\left(\mathbf{E C}_{\mathrm{a}}\right)$. Eight fields were individually partitioned into four management zones based on equal ranges of deep $\left(\mathrm{EC}_{\mathrm{DP}}\right)$ and shallow $\left(\mathrm{EC}_{\mathrm{SH}}\right) \mathrm{EC}_{\mathrm{a}}$ (approximately 0-30 and 0-90 cm depths, respectively). Previous experiments documented negative correlations between $\mathrm{EC}_{\mathrm{SH}}$ and soil properties indicative of productivity. The objectives of this study were to examine $\mathbf{E C}_{\mathrm{SH}}$ and $\mathrm{EC}_{\mathrm{DP}}$ relationships with $2 \mathrm{yr}$ of winter wheat (Triticum aestivum $\mathbf{L}$.) and corn (Zea mays $\mathbf{L}$.) yields and to consider the potential applications of $\mathbf{E C}_{\mathrm{a}}$-based management zones for SSM in a semiarid cropping system. Within-zone wheat yield means were negatively correlated with $\mathrm{EC}_{\mathrm{SH}}(r=-0.97$ to -0.99$)$ and positively correlated with $\mathrm{EC}_{\mathrm{DP}}(r=0.79-0.97)$. Within-zone corn yield means showed no consistent relationship with $\mathbf{E C}_{\mathrm{SH}}$ but positive correlation with $\mathrm{EC}_{\mathrm{DP}}(r=0.81-0.97)$. Equal-range and unsupervised classification methods were compared for $\mathrm{EC}_{\mathrm{SH}}$; within-zone yield variances declined slightly $(0-5 \%)$ with the unsupervised approach. Yield response curves relating maximum wheat yields and $\mathrm{EC}_{\mathrm{SH}}$ revealed a boundary line of maximum yield that decreased with increasing $\mathbf{E C}_{\mathrm{SH}}$. In this

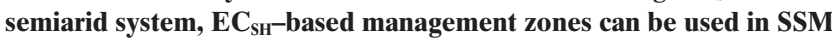
of wheat for: (i) soil sampling to assess residual nutrients and soil attributes affecting herbicide efficacy, (ii) yield goal determination, and (iii) prescription maps for metering inputs.
\end{abstract}

$\mathrm{D}$ ESPITE UNIFORM MANAGEMENT across a field, withinfield variability in crop yields is a well-recognized phenomenon. For this reason, whole-field management is increasingly viewed as inefficient because it results in the overapplication of inputs in low-producing areas and suboptimal application in areas with high-production potential. Site-specific management-the spatially directed management of soils, crops, and pests based on varying conditions within a field (Larson and Robert, 1991) - provides an alternative to the use of the field as a primary management unit. Increasing fertilizer and pesticide costs, coupled with environmental concerns stemming from their use, conceptually advance SSM as a means to improve economic (Griffith, 1995; Reetz and Fixen, 1995) and ecological outcomes in agriculture (Wallace, 1994; Castelnuovo, 1995; Larson et al., 1997).

The implementation of SSM requires real-time and accurate global positioning system (GPS) equipment,

C.K. Johnson, B.J. Wienhold, J.F. Shanahan, and J.W. Doran, USDAARS, 120 Keim Hall, Lincoln, NE 68583-0934; D.A. Mortensen, Dep. of Crop and Soil Sci., Pennsylvania State Univ., 116 ASI Building, University Park, PA 16802; Received 14 Nov. 2001. *Corresponding author (cjohnso2@bigred.unl.edu).

Published in Agron. J. 95:303-315 (2003). geographic information systems (GIS) for spatial analysis and mapping, variable-rate applicators, and input prescription maps to define management zones and direct metering devices controlling input rates (Eliason et al., 1995). While the first three components are currently available, the last, an effective and economical basis for defining site-specific inputs, is lacking. In response to this need, significant research effort has been directed toward evaluating a variety of individual and combined GIS databases as frameworks for identifying stratified within-field management zones (regions of similar production potential). These include kriged soil test point data (Mulla, 1991); soil survey maps (Robert, 1989); topography (Kravchenko et al., 2000); remote sensing (McCann et al., 1996); topography and remote sensing (Tomer et al., 1995); topography, remote sensing, and farmer experience (Fleming et al., 1999); electrical conductivity sensors (Sudduth et al., 1997; Lund et al., 1999); and yield maps (Eliason et al., 1995; Stafford et al., 1999). These approaches to SSM have met with varying degrees of success that are often highly soil or region specific.

Because some factors affecting crop yields occur unpredictably, including weather, human error, and equipment malfunction (operator error, plugged spray nozzles or planters, herbicide drift, weed pressure, poor seed viability, etc.), the potential impact of SSM may be limited in some years. At best, it will optimize the interactions between soil and inputs of nutrients, seed, or pesticides by targeting soil indices related to production potential that are measurable, relatively stable, and manageable. The productivity of a given soil is determined by the cumulative effect of natural factors involved in its formation, including climate, topography, parent material, biological activity, and time (Jenny, 1941), and management history. Management history can significantly affect the range and spatial heterogeneity of soil chemical properties beyond that attributable to natural processes. This is particularly true in organic systems where input applications are typically less uniform than in conventional systems (Cambardella and Karlen, 1999).

While variations in individual soil factors have limited utility for SSM, their combined impact on water and nutrient use efficiency is highly relevant to both production potential and environmental concerns, such as $\mathrm{NO}_{3}$ leaching (Bouma and Finke, 1993) and soil acidification (Malhi et al., 1991). Fields can be mapped for multiple

\footnotetext{
Abbreviations: $\mathrm{EC}_{\mathrm{a}}$, apparent electrical conductivity; $\mathrm{EC}_{\mathrm{DP}}$, deep apparent electrical conductivity; $\mathrm{EC}_{\mathrm{SH}}$, shallow apparent electrical conductivity; GIS, geographic information system; SSM, site-specific management.
} 
soil parameters using intensive grid sampling and interpolation. However, such techniques are often economically unfeasible, particularly in semiarid regions with predominately large-scale, dryland, low-input farms (McCann et al., 1996). For SSM to be cost effective in these regions, a surrogate measure is required, an external means for integrating and stratifying soil attributes associated with productivity. Whatever their derivation, prescription maps for SSM must satisfy two criteria. First, a strong relationship must exist between identified management zones and ground-truth soil test data, encompassing soil physical, chemical, and biological parameters underlying yield potential. Second, zones must be temporally consistent, given normal fluctuations in dynamic soil properties such as moisture and temperature. Ideally, farmers should be able to employ fieldspecific SSM prescription maps not only across seasons, but also for several years before re-evaluation.

One mapping option showing promise for SSM is soil $\mathrm{EC}_{\mathrm{a}}$. Depending on the soil factor(s) dominating measured $\mathrm{EC}_{\mathrm{a}}$ and the strength of the relationship between the factor(s) and other soil characteristics, $E_{a}$ may function as a direct and/or indirect indicator of multiple soil parameters (Sudduth et al., 1995; Doolittle et al., 1994; Jaynes et al., 1995b). For some soils, $\mathrm{EC}_{\mathrm{a}}$ mapping appears to integrate soil parameters related to productivity to produce a template of potential yield (Jaynes et al., 1993; Sudduth et al., 1995; Kitchen et al., 1999). Because most $\mathrm{EC}_{\mathrm{a}}$ research has been conducted in humid areas of the United States with high rates of precipitation, very little is known about the relationships among $\mathrm{EC}_{\mathrm{a}}$, soil properties, and crop yields in semiarid regions.

In a farm-scale study in semiarid northeastern Colorado, Johnson et al. (2001) found that management zones based on $\mathrm{EC}_{\mathrm{a}}$ mapping (approximately 0-30 $\mathrm{cm}$ depth of measurement) provide a useful basis for soil sampling. Such zones also fulfill the first criteria for SSM prescription maps by effectively delineating within-field regions of varying production potential. Other published research indicates that spatial patterns in $\mathrm{EC}_{\mathrm{a}}$ do not change with temporal variation in soil moisture and/ or temperature (Lund et al., 1999; Sudduth et al., 2001). These findings advance $\mathrm{EC}_{\mathrm{a}}$ mapping as a basis for SSM.

The primary objective of this study was to examine the relationships between $\mathrm{EC}_{\mathrm{a}}$-based management zones and crop yields in a 4-yr crop rotation in the semiarid central Great Plains. Specifically, 2 yr of yield maps from two fields each of corn and winter wheat, two depths of $E_{\mathrm{a}}$ measurement (approximately $0-30 \mathrm{~cm}$ and $0-90 \mathrm{~cm}$ ), and two methods for stratifying $\mathrm{EC}_{\mathrm{a}}$ into management zones (unsupervised and equal-size classification) were evaluated. A secondary objective was to consider the significance and potential application of $\mathrm{EC}_{\mathrm{a}}$-based management zones for SSM in a semiarid cropping system. This second objective was supported by previous findings regarding the relationships between $\mathrm{EC}_{\mathrm{SH}}$ and soil physical, chemical, and biological properties (Johnson et al., 2001).

\section{MATERIALS AND METHODS}

\section{Site}

This research was conducted on the farmer-owned and managed Farm-Scale Intensified Cropping Study, first described by Johnson et al. (2001), located approximately $30 \mathrm{~km}$ east of the town of Sterling in northeastern Colorado $\left(40^{\circ} 36^{\prime} \mathrm{N}\right.$, $\left.103^{\circ} \mathrm{W}\right)$. The site encompasses a contiguous section of farmland, approximately 250 ha. It is located in the heart of the central Great Plains where highly variable precipitation averages $420 \mathrm{~mm}$ annually. Soils are comprised of a mixture of Platner, Weld, and Rago loam soils (fine, smectitic, mesic, Aridic Paleustolls and fine, smectitic, mesic Pachic Argiustolls) with 0 to $5 \%$ slope.

In 1999, the experimental site was converted from a conventionally tilled wheat-fallow system to a no-tillage, high-intensity winter wheat-corn-proso millet (Panicum miliaceum L.) fallow rotation. Each of the four crop treatments is applied to two fields (approximately 31 ha each) in a given year (Fig. 1).

\section{Data Collection}

Data layers that were analyzed and compared included: (i) maps of $\mathrm{EC}_{\mathrm{a}}$ collected at two depths of measurement, $\mathrm{EC}_{\mathrm{SH}}$ $(0-30 \mathrm{~cm})$ and $\mathrm{EC}_{\mathrm{DP}}(0-90 \mathrm{~cm})$; (ii) the map of $\mathrm{EC}_{\mathrm{SH}}$ classified into four zones based on unsupervised classification; (iii) maps of $\mathrm{EC}_{\mathrm{SH}}$ and $\mathrm{EC}_{\mathrm{DP}}$ classified into four zones of equal size (containing the same number of $\mathrm{EC}_{\mathrm{a}}$ observations); and (iv) $2 \mathrm{yr}$ of corn and winter wheat yield maps. All yield and $\mathrm{EC}_{\mathrm{a}}$ mapping was georeferenced using a Trimble AG132 D GPS receiver (Trimble Navigation, Sunnyvale, CA) ${ }^{1}$ with submeter accuracy.

Yield maps were taken from corn and wheat fields in 1999 (Fields no. 3 and 6 for corn and Fields no. 5 and 8 for wheat) and 2000 (Fields no. 5 and 8 for corn and fields no. 1 and 4 for wheat) (Fig. 1). Data collected with a Micro-Trak grain yield monitor (Micro-Trak Syst., Eagle Lake, MN) ${ }^{1}$ were verified with grain weigh-ticket information (total bushels, moisture content, and test weight) and mapped using Farm HMS software (Red Hen Syst., Fort Collins, CO). ${ }^{1}$

\section{Mapping and Classification of Apparent Soil Electrical Conductivity}

The entire site was $\mathrm{EC}_{\mathrm{a}}$-mapped in March 1999 by direct contact (15-m swath width at a speed of $\left.4.5 \mathrm{~m} \mathrm{~s}^{-1}\right)$, using a Veris 3100 Sensor Cart (Veris Technol., a division of Geoprobe Syst., Salina, KS $)^{1}$ (Fig. 1). Calibrations were performed according to manufacturer instructions. Latitude, longitude, and $\mathrm{EC}_{\mathrm{SH}}$ and $\mathrm{EC}_{\mathrm{DP}}$ readings $\left(\mathrm{mS} \mathrm{m}^{-1}\right)$ were recorded at 1-s intervals by the Veris datalogger. Values of $\mathrm{EC}_{\mathrm{a}}$ were converted to $\mathrm{dS}$ $\mathrm{m}^{-1}$ for reporting. All fields were uncropped at the time of mapping, except for Fields 5 and 8 (Fig. 1), which were planted to winter wheat.

The $\mathrm{EC}_{\mathrm{a}}$ raw (point) data files were projected to UTM (Universal Transverse Mercator) coordinates in the NAD83 datum (North American Datum of 1983) in ArcInfo (ESRI, Redlands, CA). ${ }^{1}$ They were then interpolated by inverse-distance weighting using the nearest-neighbor technique and redefined as grid files (10-m grid cell resolution). Four management zones based on ranges of $\mathrm{EC}_{\mathrm{SH}}$ and $\mathrm{EC}_{\mathrm{DP}}$ (low, medium low, medium high, and high) were determined for each of the eight fields comprising the study site using a method called equal-size classification. The number of $\mathrm{EC}_{\mathrm{SH}}$ or $\mathrm{EC}_{\mathrm{DP}}$ grid cells in each field was tallied and divided by four to identify four zones approximately equal in area.

\footnotetext{
${ }^{1}$ Mention of a trademark, proprietary product, or vendor does not constitute a guarantee of or warranty of the product by USDA nor imply its approval to the exclusion of other products that may be suitable.
} 


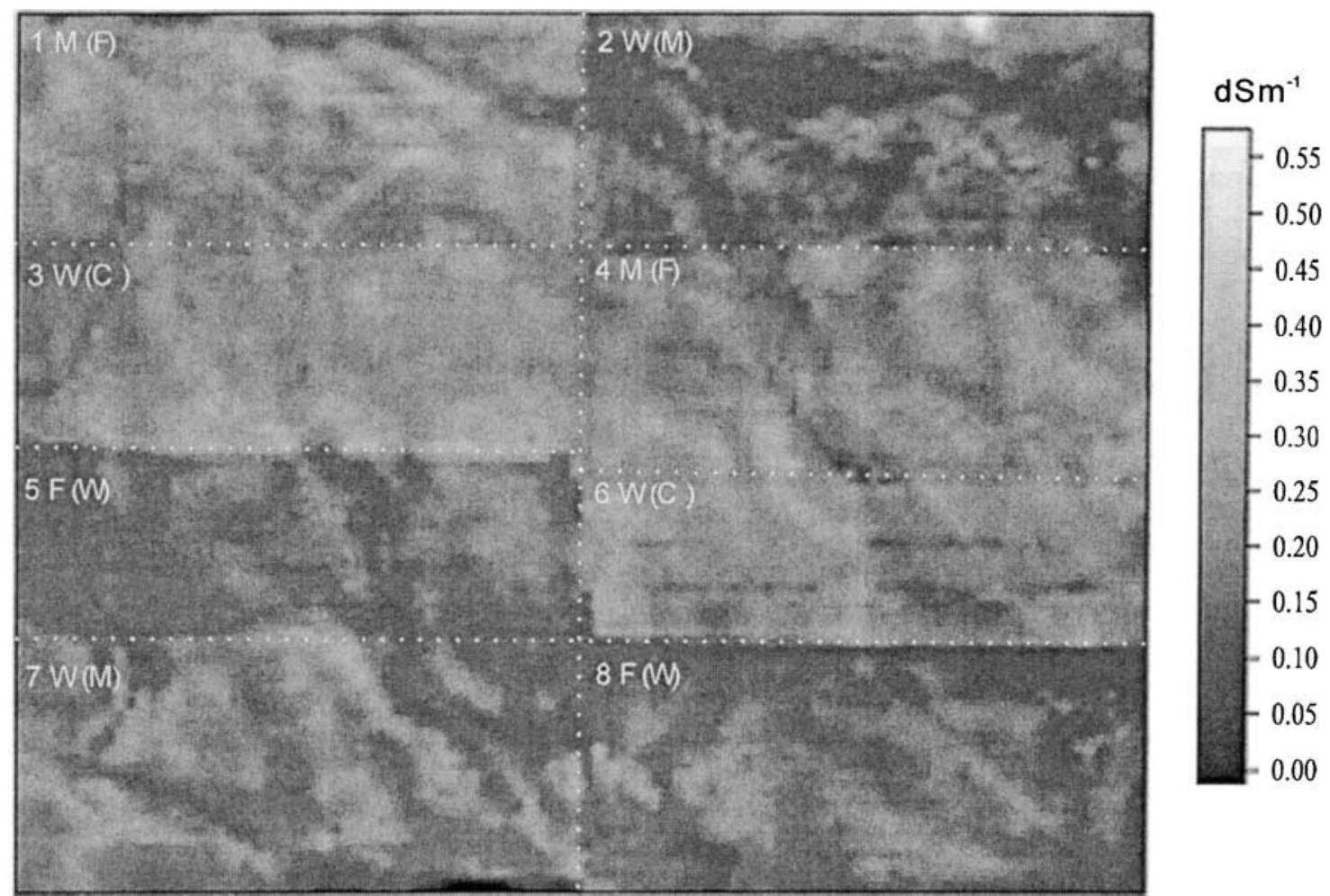

Fig. 1. Experimental layout superimposed on the March 1999 shallow (approximately 0-30 cm depth of measurement) apparent electrical conductivity map of the 250 -ha site. Field numbers, followed by cropping treatments-winter wheat (W), corn (C), proso millet (M), and fallow (F)—for 1998 and 1999 (in parenthesis) are shown in the upper left-hand corner of each field.

In addition to equal-size classes, $\mathrm{EC}_{\mathrm{SH}}$ maps were classified using a second method termed unsupervised classification (ERDAS, 1997). ${ }^{1}$ Unsupervised classification uses an iterative process to group clusters of statistically similar data. The $\mathrm{EC}_{\mathrm{SH}}$ maps from each of the eight fields in the study site were individually interpolated by inverse-distance weighting and classified using unsupervised classification to form 12 classes within each field at a 10-m grid cell resolution. The 12 classes were then recoded into four ranges of $\mathrm{EC}_{\mathrm{SH}}$ : low, medium low, medium high, and high. Recoding is a highly subjective process wherein the 12 original unsupervised classes of $\mathrm{EC}_{\mathrm{SH}}$ were combined to mimic the dominant visible spatial patterns seen in the original grayscale $\mathrm{EC}_{\mathrm{SH}}$ maps (Fig. 2). Through this process, $\mathrm{EC}_{\mathrm{SH}}$ measurements (pixels) were aggregated into naturally occurring clusters that may reduce within-zone variance.

\section{Soil Sampling}

A soil-sampling scheme was developed based on management zones assigned by unsupervised classification of $\mathrm{EC}_{\mathrm{SH}}$. For each of the eight fields in the study site, three representative georeferenced soil-sampling sites were arbitrarily selected within each of the four management zones to total 96 sites across the section (Fig. 3). Sites were identified near the center of distinct, nonadjoining sections within each $\mathrm{EC}_{\mathrm{SH}}$ zone to avoid transition areas. They were placed in a manner to minimize clustering and provide comprehensive coverage of each field (Fig. 2). Because the long-term objective of this study is to track management effects on soil condition and production potential that occur primarily at the surface, soils were evaluated in the top $30 \mathrm{~cm}$ only. Seven $4-\mathrm{cm}$-diam. soil cores were collected, composited, and mixed from each sampling site at depths of 0 to 7.5 and 7.5 to $30 \mathrm{~cm}$.

A variety of soil analyses were conducted to assess physical (bulk density, soil texture, and water content), chemical (labo- ratory-measured electrical conductivity, $\mathrm{NH}_{4}-\mathrm{N}, \mathrm{NO}_{3}-\mathrm{N}$, wholesoil organic matter, particulate organic matter, $\mathrm{pH}$, extractable $\mathrm{P}$, and total $\mathrm{C}$ and $\mathrm{N}$ ), and biological (microbial biomass $\mathrm{C}$ and $\mathrm{N}$ and potentially mineralizable $\mathrm{NH}_{4}$ ) soil parameters defining intrinsic soil fertility. Data in Table 1 represents 0 - to $30-\mathrm{cm}$ depth soil characteristics calculated from combined and weighted 0 - to 7.5 - and 0 - to $30-\mathrm{cm}$ depth analyses. Johnson et al. (2001) provide additional information on soil collection and analysis.

\section{Manipulation and Analysis of GIS Data Layers}

As with $\mathrm{EC}_{\mathrm{a}}$ maps, winter wheat and corn yield map raw data files were imported into ArcInfo (ESRI, Redlands, CA) where they were projected to UTM coordinates in the NAD83 datum, interpolated by inverse-distance weighting using the nearest-neighbor technique, and redefined as grid files $(10-\mathrm{m}$ grid cell resolution). To align gridded $\mathrm{EC}_{\mathrm{a}}$ and yield maps with each other and with classified-EC $\mathrm{C}_{\mathrm{a}}$ maps, all data layers were snapped into identical georeferenced positions by defining the furthermost northwest and southeast points of the experimental site (boundary control points). In this format, data layers were superimposed to create a grid stack wherein corresponding georeferenced data could be exported in spreadsheet format for statistical evaluation.

Both $\mathrm{EC}_{\mathrm{SH}}$ and $\mathrm{EC}_{\mathrm{DP}}$ were compared with winter wheat and corn yield maps for significant associations using ANOVA and regression techniques. Relationships between yield and $\mathrm{EC}_{\mathrm{a}}$-classified data layers were assessed by ANOVA for a randomized complete block design with $\mathrm{EC}_{\mathrm{SH}}$ or $\mathrm{EC}_{\mathrm{DP}}$ zones (identified using equal-size and/or unsupervised classification) as a treatment factor. All statistical analyses were performed using SAS (SAS Inst., 1997), ${ }^{1}$ and differences were declared significant at the 0.05 level, unless stated otherwise. 

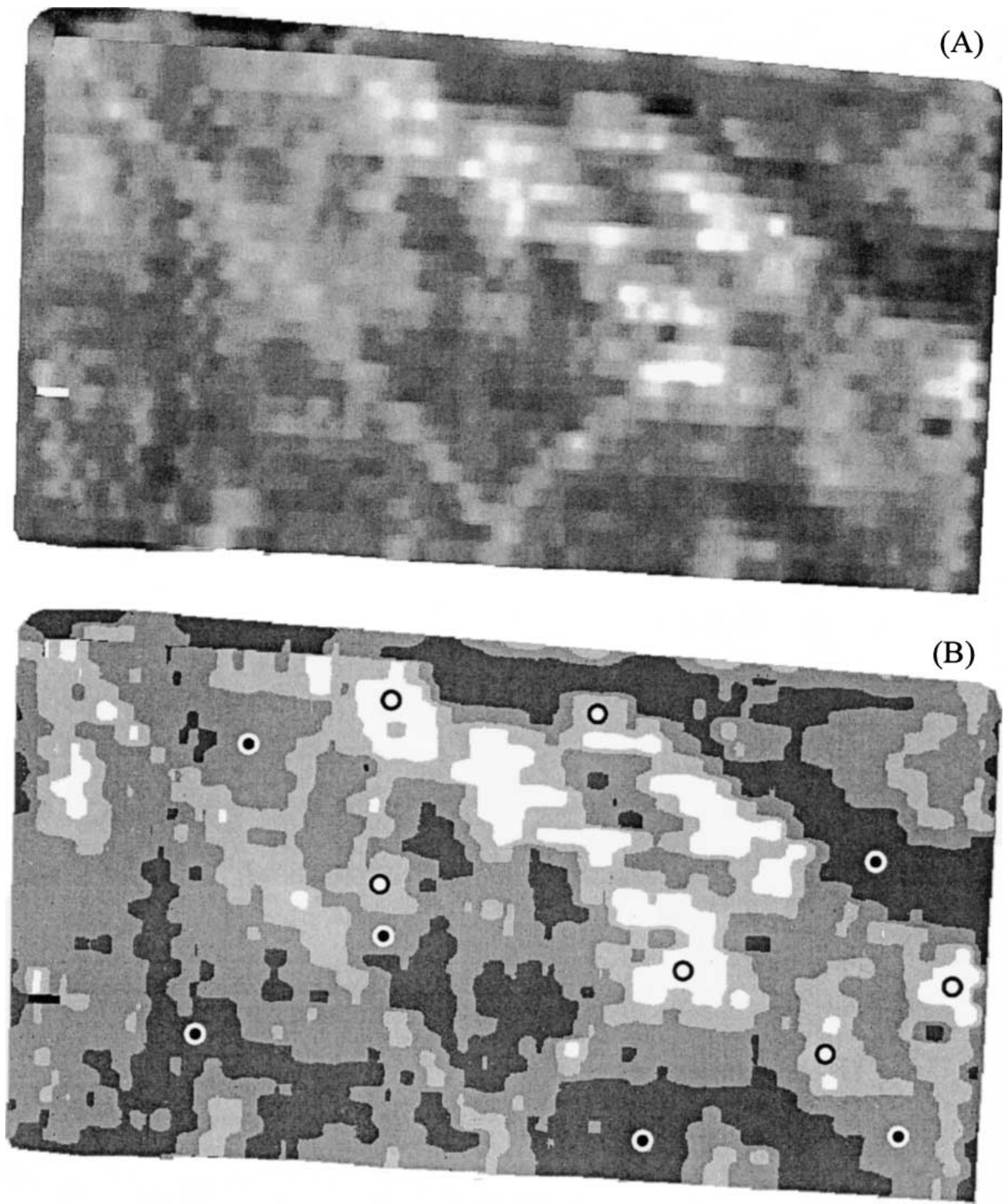

Fig. 2. A gray-scale shallow (approximately 0-30 cm depth of measurement) apparent electrical conductivity map for (A) Field 1 and (B) following unsupervised classification and recoding into four electrical conductivity management zones. Variations in color, from dark to light, correspond to increasing conductivity, and $\bigcirc$ symbols represent selected soil-sampling sites.

\section{RESULTS AND DISCUSSION}

Apparent Electrical Conductivity

(0-30 and 0-90 cm Depths of Measurement) versus Crop Yield

Table 1 illustrates the across-site range and means of $\mathrm{EC}_{\mathrm{SH}}$ within $\mathrm{EC}_{\mathrm{SH}}$ zones and the within- $\mathrm{EC}_{\mathrm{SH}}$ zone range, distribution, and significance for selected soil parameters sampled from the study site (Johnson et al., 2001).
In this semiarid region, bulk density, clay content, and $\mathrm{pH}$-soil properties associated with erosion-were positively correlated with $\mathrm{EC}_{\mathrm{SH}}$. Conversely, water content, soil organic matter, $\mathrm{C}$ and $\mathrm{N}$, and extractable $\mathrm{P}$ - properties indicative of yield potential-were negatively correlated with $\mathrm{EC}_{\mathrm{SH}}$. These findings predicted a negative correlation between $\mathrm{EC}_{\mathrm{SH}}$ and yield that was corroborated by 1999 (Fields 5 and 8) and 2000 (Fields 1 and 4) wheat yield maps (Fig. 4). 


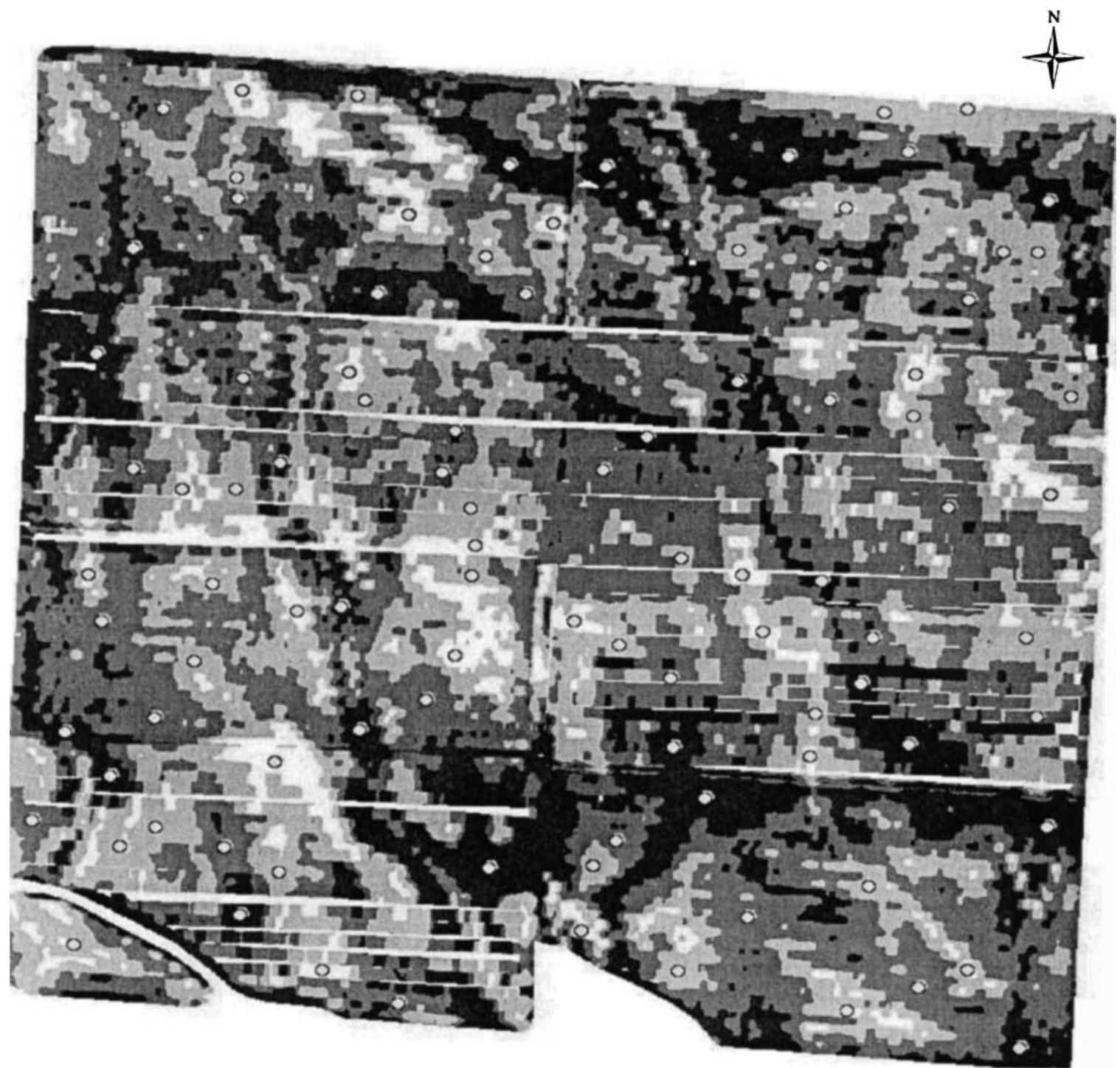

Fig. 3. Classified apparent electrical conductivity $\left(\mathrm{EC}_{\mathrm{a}}\right)$ map (applying the unsupervised classification method to $0-30 \mathrm{~cm}$ depth of $\mathrm{EC}_{\mathrm{a}} \mathrm{measure-}$ ment) and soil-sampling scheme for the 250 -ha experimental site.

The regression of mean yield within $\mathrm{EC}_{\mathrm{SH}}$ class against mean $\mathrm{EC}_{\mathrm{SH}}$ within $\mathrm{EC}_{\mathrm{SH}}$ class, for each of the fields planted to wheat during these $2 \mathrm{yr}$, revealed strong and consistent relationships between the two data layers $\left(r^{2}=0.99\right.$ with equal-size classification). This was true even though wheat yields were significantly greater in 1999 than in 2000. Whole-field averages were 2958 and $3401 \mathrm{~kg} \mathrm{ha}^{-1}$ (Fields 5 and 8) in 1999 compared with 2398 and $2476 \mathrm{~kg} \mathrm{ha}^{-1}$ (Fields 1 and 4) in 2000 . For the region, 1999 and 2000 represent above-average- and typical-yielding years for wheat, respectively. Figure 4 also shows that the magnitude of wheat yield improvement, among zones of decreasing $\mathrm{EC}_{\mathrm{SH}}$, was greatest in the higher yielding 1999. Through increased (yield potential-based) application rates of inputs currently limiting yields in the best-producing areas of these fields, SSM has the potential to heighten yield differences among management zones to an even greater degree.

The relationship between $\mathrm{EC}_{\mathrm{SH}}$ and yield, while applicable to wheat, did not hold across crops for the $2 \mathrm{yr}$ evaluated. Although ANOVA showed significant $(P \leq$ $0.0001)$ associations between $\mathrm{EC}_{\mathrm{SH}}$ and yield for three of four corn fields evaluated (Field 3 in 1999 and Fields 5 and 8 in 2000), these relationships were not consistent (Table 2). When regressing mean corn yields within $\mathrm{EC}_{\mathrm{SH}}$ class against mean $\mathrm{EC}_{\mathrm{SH}}$ within $\mathrm{EC}_{\mathrm{SH}}$ class, only Field 8 showed significant linearity $\left(r^{2}=0.90\right.$ with equalsize classification) (Fig. 4).

The relationships between $\mathrm{EC}_{\mathrm{a}}$ and crop yields also varied with the depth of $\mathrm{EC}_{\mathrm{a}}$ measurement. Comparison of mean $\mathrm{EC}_{\mathrm{DP}}$ within $\mathrm{EC}_{\mathrm{DP}}$ zones to mean winter wheat and corn yields within $\mathrm{EC}_{\mathrm{DP}}$ zones revealed positive correlations between $\mathrm{EC}_{\mathrm{DP}}$ and yield across years for both crops (Table 2). Thus, while only $\mathrm{EC}_{\mathrm{DP}}$ adequately described corn yields, either $\mathrm{EC}_{\mathrm{SH}}$ or $\mathrm{EC}_{\mathrm{DP}}$ provided a useful basis for identifying management zones for winter wheat. Yet, winter wheat yield separation among $\mathrm{EC}_{\mathrm{a}}$ zones, for the highest-yielding zones of three of four fields evaluated (Fields 4, 5, and 8), was greatest when these zones were based on $\mathrm{EC}_{\mathrm{SH}}$ (Table 2). Management 
Table 1. Apparent electrical conductivity $\left(\mathbf{E C}_{\mathrm{a}}\right)$ ranges, $\mathbf{E C}_{\mathrm{a}}$ means, and significance of soil physical and chemical parameters sampled postharvest (0-30 cm depth) within $\mathbf{E C}_{\mathrm{a}}$ management zones (Johnson et al., 2001). Zones were based on shallow EC $\mathbf{C}_{\mathrm{a}}$ (approximately $0-30 \mathrm{~cm}$ depth of measurement) and were identified using unsupervised classification. Analyses of variance were run across replicates and fields.

\begin{tabular}{|c|c|c|c|c|c|c|c|c|c|c|}
\hline & $\begin{array}{c}\mathbf{E C}_{\mathrm{a}} \\
\text { ranges }\end{array}$ & $\begin{array}{c}\mathbf{E C}_{\mathrm{a}} \\
\text { means }\end{array}$ & Clay & $\begin{array}{c}\text { Bulk } \\
\text { density }\end{array}$ & pH & $\begin{array}{c}\text { Water } \\
\text { content }\end{array}$ & SOM $\dagger$ & $\begin{array}{c}\text { Extractable } \\
\mathbf{P}\end{array}$ & Total C & Total N \\
\hline & \multicolumn{2}{|c|}{$\longrightarrow \mathrm{dS} \mathrm{\textrm {m } ^ { - 1 }}$} & $\%$ & $\mathrm{~g} \mathrm{~cm}^{-3}$ & & $\mathrm{~kg} \mathrm{~kg}^{-1}$ & $\operatorname{Mg~ha}^{-1}$ & $\mathrm{~kg} \mathrm{ha}^{-1}$ & $\longrightarrow \mathbf{N}$ & ${ }^{-1}$ \\
\hline EC $_{\mathrm{a}}$ zone & & $* *$ & $*$ & 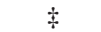 & $* *$ & $*$ & *** & $* *$ & $* *$ & $* *$ \\
\hline Low & $0.00-0.17$ & 0.12 & 22.8 & 1.32 & 6.33 & 0.207 & 124.8 & 111.8 & 43.8 & 4.08 \\
\hline Med. low & $0.12-0.23$ & 0.17 & 24.3 & 1.39 & 6.42 & 0.187 & 115.9 & 69.2 & 35.2 & 3.45 \\
\hline Med. high & $0.14-0.29$ & 0.23 & 27.3 & 1.39 & 6.72 & 0.185 & 110.4 & 27.8 & 32.2 & 3.09 \\
\hline High & $0.18-0.78$ & 0.30 & 28.1 & 1.42 & 6.92 & 0.178 & 112.6 & 26.7 & 32.7 & 3.10 \\
\hline
\end{tabular}

* Significant at the 0.05 level.

** Significant at the 0.01 level.

$\dagger$ SOM, soil organic matter.

+ Significant at the 0.10 level.

zones based on $\mathrm{EC}_{\mathrm{DP}}$ significantly partitioned corn yields in three of four fields examined (Field 3 and 6 in 1999 and Field 8 in 2000). The remaining corn field (Field 5 in 2000) had the lowest overall yield of the four fields and little across-field yield variation, likely causes of poor yield discrimination among classes. These findings indicate that for the $2 \mathrm{yr}$ examined, $\mathrm{EC}_{\mathrm{SH}}$ provided the best basis for management zone determination in winter wheat while $\mathrm{EC}_{\mathrm{DP}}$ better integrated those soil characteristics defining corn yield.

The disparity in relationships between $\mathrm{EC}_{\mathrm{SH}}$ and yields of corn and wheat may simply reflect differences in crop response to both the soil factors contributing to measured $\mathrm{EC}_{\mathrm{SH}}$ and to other soil factors with which they are

\section{9}

Unsupervised
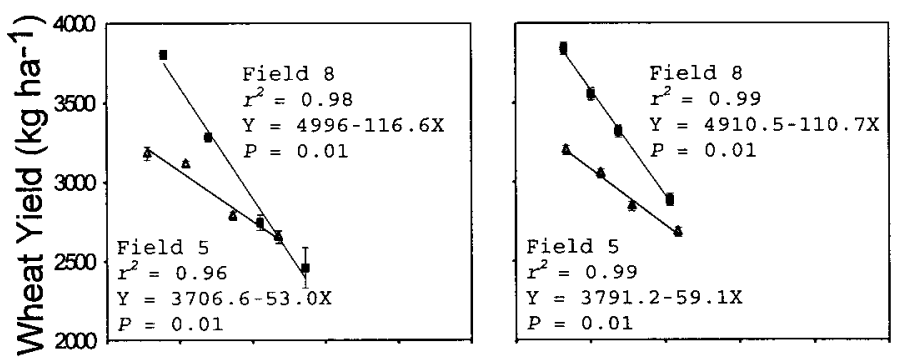

Equal Size
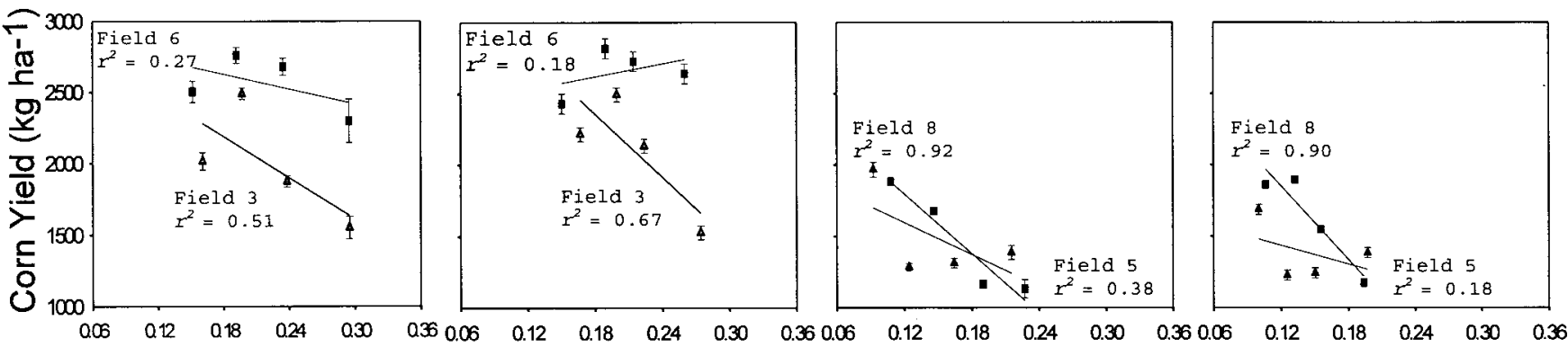

\section{$\mathrm{EC}_{\mathrm{SH}}\left(\mathrm{dS} \mathrm{m} \mathrm{m}^{-1}\right)$}

Fig. 4. Mean wheat and corn yields for 1999 and 2000 within management zones based on unsupervised and equal-size classification of shallow electrical conductivity $\left(\mathrm{EC}_{\mathrm{SH}}\right.$ ) (approximately $0-30 \mathrm{~cm}$ depth of measurement) regressed against mean $\mathbf{E C}_{\mathrm{SH}}$ within $\mathbf{E C}_{\mathrm{SH}} \mathrm{zones}$. The error bars represent the standard error of the mean.

correlated. It has been documented that factors affecting yield variability may differ among crops (Vieira, 1999). Yet, different water stress levels between corn and wheat across the $2 \mathrm{yr}$ studied and limitations in $\mathrm{EC}_{\mathrm{SH}}$ effectiveness for delineating soil factors associated with rootzone water availability may better explain the divergence in $\mathrm{EC}_{\mathrm{SH}}$-yield relationships for corn and wheat. Because its growing season corresponds well with preipitation patterns for the region, wheat is a more suitable crop for the central Great Plains than is corn. In addition, greater soil water storage due to the rotational sequencing of wheat after fallow improves water availability to that crop. These factors reduce water stress on wheat crops to benefit yield and yield consistency across

\section{0}

Unsupervised

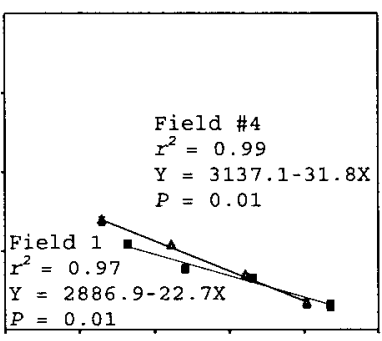

Field $1:$

$r^{2}=0.99$
$Y=2812.6-19.5 X$ $P=0.01$

Equal Size

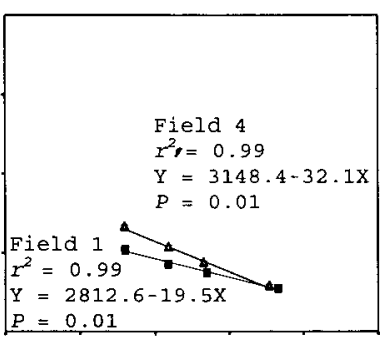


years. Previous experiments describing the soil characteristics of $\mathrm{EC}_{\mathrm{SH}^{-}}$-delineated zones indicate that $\mathrm{EC}_{\mathrm{SH}}$ is highly correlated with soil water, organic matter content, and total $\mathrm{C}$ and $\mathrm{N}$, all indicators of improved waterholding capacity (Johnson et al., 2001). These surface soil characteristics appear to be essential determinants of winter wheat yield in the typical and high-yielding years encountered during this study.

Conversely, the corn growing season spans a period of low precipitation and high evaporative demand that diminishes water availability and water use efficiency. Furthermore, corn follows wheat in the rotation under study, making yields more susceptible to annual variations in precipitation. For these reasons, corn yields in the central Great Plains are particularly vulnerable to water stress during a 6 -wk period between 15 July and 25 August; precipitation rates within this period explain $70 \%$ of the variability in corn yields (Nielsen, 1996). Corn crops in both 1999 and 2000 were highly drought stressed during this critical time. Consequently, yields were low in 1999, averaging 2092 and $2654 \mathrm{~kg} \mathrm{ha}^{-1}$ (Fields 3 and 6), and poor in 2000, averaging 1386 and $1621 \mathrm{~kg}$ $\mathrm{ha}^{-1}$ (Fields 5 and 8). Climatic influences, particularly variability in precipitation timing and quantity, appear to diminish or confound the impact that underlying surface soil characteristics, integrated by $\mathrm{EC}_{\mathrm{SH}}$, have on corn yields. It is possible that, in a year with higher precipitation during July and August, corn yields would present the same negative association with $\mathrm{EC}_{\mathrm{SH}}$ identified for wheat. Further studies are required to investigate this possibility.

Other investigators have found highly variable relationships between corn yields and various methods for delineating management zones. A study in the southeastern USA by Sadler et al. (1995) examined correlations between corn yields and soil condition delineated by soil survey map units. They documented the variable response of corn yield, rainfall partitioning, and water use efficiency both among and within map units in dry years. In western Iowa, Jaynes et al. (1995a) found inconsistent correlations between corn and soybean yields and electrical conductivity (approximately $0-150 \mathrm{~cm}$ depth of measurement) in high- and low-precipitation years, both among fields and across years. They hypothesized that this resulted from opposing responses among electrical conductivity-delineated zones, to low vs. excessive soil moisture, causing heightened yield variability within fields. In semiarid regions, yield reductions from excessive precipitation are rare. Thus, electrical conductivity-delineated management zones may be a more reliable indicator of corn yield potential and, therefore, a more useful basis for SSM in these regions than in those receiving higher rates of precipitation.

Measured soil $\mathrm{EC}_{\mathrm{a}}$ is a function of salinity, clay type and percentage, water content, bulk density, and temperature (Rhoades et al., 1989; McNeill, 1980). Findings by Johnson et al. (2001) indicate that the primary drivers of $\mathrm{EC}_{\mathrm{SH}}$ at the Farm-Scale Intensive Cropping Study are clay content and $\mathrm{CaCO}_{3}$ salts (contributing to increased soil $\mathrm{pH}$ at high $\mathrm{EC}_{\mathrm{SH}}$ ) (Table 1). Increases in these soil properties are characteristic of eroded parts of a field. Therefore, a negative correlation exists between $\mathrm{EC}_{\mathrm{SH}}$ and soil characteristics associated with yield potential. Conversely, decreases in surface clay content and $\mathrm{CaCO}_{3}$ correlate with other soil properties that improve waterholding capacity, nutrient exchange, and plant rooting depth (increase yield potential).

Because soil assessments corresponding to $\mathrm{EC}_{\mathrm{DP}}$ were not made, we must hypothesize the reason(s) for the reversal in relationship between (wheat and corn) crop yields and $\mathrm{EC}_{\mathrm{DP}}$ compared with that between wheat yields and $\mathrm{EC}_{\mathrm{SH}}$. Because water is the greatest limiting factor

Table 2. Comparison of 1999 and 2000 winter wheat and corn yield averages and significance within apparent electrical conductivity $\left(\mathrm{EC}_{\mathrm{a}}\right)$ zones classified based on shallow and deep $\mathrm{EC}_{\mathrm{a}}$ measurements (approximately 0-30 and 0-90 cm depths, respectively). Zones were determined for each depth of measurement using equal-size $\mathbf{E C}_{\mathrm{a}}$ classification.

\begin{tabular}{|c|c|c|c|c|c|c|c|c|}
\hline & \multicolumn{4}{|c|}{1999} & \multicolumn{4}{|c|}{2000} \\
\hline & \multicolumn{4}{|c|}{ Approximate depth of $\mathbf{E C}_{\mathrm{a}}$ measurement, $\mathrm{cm}$} & \multicolumn{4}{|c|}{ Approximate depth of $\mathbf{E C}_{\mathrm{a}}$ measurement, $\mathrm{cm}$} \\
\hline & 0-30 & 0-90 & 0-30 & 0-90 & 0-30 & 0-90 & 0-30 & 0-90 \\
\hline & \multicolumn{2}{|c|}{ Field 5} & \multicolumn{2}{|c|}{ Field 8} & \multicolumn{2}{|c|}{ Field 1} & \multicolumn{2}{|c|}{ Field 4} \\
\hline & & & & - Whea & $\mathrm{g} \mathrm{ha}^{-1}$ & & & \\
\hline EC $_{\mathrm{a}}$ zones & $* * *$ & $* * *$ & $* * *$ & $* * *$ & $* * *$ & $* * *$ & $* * *$ & $* * *$ \\
\hline Low & $3201 a \dagger$ & $2659 c$ & 3843a & $2913 c$ & 2519a & 2222d & 2660a & $2384 c$ \\
\hline Med. low & $3052 b$ & $2872 b$ & $3554 \mathrm{~b}$ & 3463b & $2429 b$ & $2357 \mathrm{c}$ & $2530 b$ & $2471 b$ \\
\hline Med. high & $2846 c$ & 3088a & $3319 c$ & 3621a & $2374 c$ & $2462 b$ & $2431 c$ & 2504ab \\
\hline \multirow{4}{*}{$\underset{\mathbf{S E}_{d}}{\text { High }}$} & $2683 d$ & $3163 a$ & 2887d & 3608a & 2273d & $2555 a$ & 2283d & $2545 a$ \\
\hline & 30 & 30 & 38 & 39 & 18 & 18 & 16 & 16 \\
\hline & \multicolumn{2}{|c|}{ Field 3} & \multicolumn{2}{|c|}{ Field 6} & \multicolumn{2}{|c|}{ Field 5} & \multicolumn{2}{|c|}{ Field 8} \\
\hline & & & & - Corn & $\mathbf{h a}^{-1}$ & & & \\
\hline $\mathbf{E C}_{\mathrm{a}}$ zones & $* * *$ & $* * *$ & $* * *$ & $* * *$ & $* * *$ & NS\$ & **** & $* * *$ \\
\hline Low & $2215 b$ & 1029d & $2430 b$ & 1381d & $1687 a$ & 1338b & $1862 a$ & $1405 d$ \\
\hline Med. low & 2492a & $1704 c$ & 2818a & $2154 c$ & $1228 \mathrm{c}$ & 1400ab & 1895a & $1575 c$ \\
\hline Med. high & 2132b & $2630 b$ & 2727a & 3249b & $1244 c$ & 1355ab & $1550 \mathrm{~b}$ & $1714 b$ \\
\hline High & $1527 \mathrm{c}$ & 3007a & 2640a & 3834a & $1386 b$ & 1452a & $1177 \mathrm{c}$ & 1789a \\
\hline$\stackrel{S}{S} E_{d}$ & 49 & 41 & 70 & 58 & 36 & 36 & 24 & 26 \\
\hline
\end{tabular}

*** Comparison of $\mathbf{E C}_{\mathrm{a}}$ zone treatments significant at the 0.001 level.

$\dagger$ Values followed by the same letter within $\mathrm{EC}_{\mathrm{a}}$ zones are not significantly different (0.10).

+ Standard error of the difference between sample means.

$\S$ NS, nonsignificant $F$ value at the 0.1 level. 
to crop production in the central Great Plains, positive correlations between yield and $\mathrm{EC}_{\mathrm{DP}}$ must be linked to soil water content, particularly given that corn crops were highly drought stressed during both years examined. These findings indicate that $\mathrm{EC}_{\mathrm{DP}}$ is driven by soil water content, salts in the soil solution, and clay content, which at 0 - to $90-\mathrm{cm}$ depths likely both contributes to measured $\mathrm{EC}_{\mathrm{a}}$ and correlates with soil water-holding capacity. Probable factors controlling salinity of the soil solution are residual $\mathrm{NO}_{3}$ and $\mathrm{NH}_{4}$ and $\mathrm{CaCO}_{3}$. Measured $\mathrm{EC}_{\mathrm{DP}}$ may also reflect soil depth to lime present in the $\mathrm{C}$ horizon. Further research is needed to test associations among soil characteristics, crop yields, and $\mathrm{EC}_{\mathrm{DP}}$.

\section{Unsupervised versus Equal-Size Shallow Apparent Electrical Conductivity Classification}

Classification is the partitioning of soil into regions of similar production potential as a means to describe within-field variability and create management zones. Clearly, for this study site, there exists a strong linear relationship between $\mathrm{EC}_{\mathrm{SH}}$ and wheat yields, allowing for the identification of $\mathrm{EC}_{\mathrm{SH}_{\mathrm{H}}}$-delineated management zones based on ranges of $\mathrm{EC}_{\mathrm{SH}}$. Yet, how should these ranges be assigned? Classes may be defined using threshold values of either soil properties critical to productivity or regions of differing soil morphology (Lark, 1997). If these threshold values delineate levels of intrinsic soil fertility, they may present an ideal basis for SSM. Van Uffelen et al. (1997) applied a weighted distance measure to identify patterns in simulated yield maps for this purpose. Lark and Stafford (1997) used fuzzy multivariate clustering analysis to define heterogeneous management zones based on $3 \mathrm{yr}$ of actual yield data. Yet, for farmers to adopt SSM, the development of management zones must be simple, functional, and economically feasible. Complex field assessments and data manipulation may not be justifiable in terms of time, benefit, or economics.

Unsupervised classification, one method for identifying $\mathrm{EC}_{\mathrm{a}}$ management zones, is based on the assumption that grouping $\mathrm{EC}_{\mathrm{a}}$ data points into naturally occurring clusters (ranges) will reduce within-zone yield variability. It represents a simplified approach for identifying threshold parameters related to yield potential. Table $3 \mathrm{com}-$ pares unsupervised and equal-size classification methods.
For three of four wheat fields evaluated, $\mathrm{EC}_{\mathrm{SH}}$ management zones derived from unsupervised classification showed increased $F$ values over equal-size methods. Comparison of $F$ values offers a rough estimate of the power of the two methods to separate yields. For the same three fields, unsupervised classification decreased variance within $\mathrm{EC}_{\mathrm{SH}}$ zones compared with equal-size methods. Fraisse et al. (2001) compared whole-field yield variance (one management zone) to yield variances calculated when fields were divided into one to six management zones using unsupervised classification. Yield variances associated with different numbers of management zones were expressed as a percentage of whole-field yield variance. Percentages were compared to determine which number of zones best reduced within-zone variance (increased between-zone variance) as a means to identify the optimal number of management zones for each field. Applying this approach to compare unsupervised and equalsize classification methods revealed a 0 and $5 \%$ reduction in yield variance with unsupervised classification (Table 3 ). Thus, differences in wheat yield partitioning due to classification method are subtle (Table 3 and Fig. 4), an indication that either unsupervised or equal-size classification methods may be acceptable bases for SSM.

Yield distribution and frequency among $\mathrm{EC}_{\mathrm{SH}}$ management zones is shown for both classification methods (Fig. 5). Unsupervised classification partitioned a greater percentage of land area into low-end $\mathrm{EC}_{\mathrm{SH}}$ zones, particularly in the medium-low zone, at the expense of allocation into the high-EC $\mathrm{EC}_{\mathrm{SH}}$ zone. As a result, wheat yield standard errors within zones decreased in medium-low zones in all fields examined when unsupervised classification was used (Table 3). Therefore for this site, equalsize classification promotes the relatively even dispersal of seed, herbicide, and fertilizer inputs across fields while unsupervised classification will require higher total inputs. A farmer's personal observations of temporal and spatial variability in yield (the degree of heterogeneity) may be the best basis for deciding both the number of management zones to be assigned and the classification method to be applied to an individual field.

An additional consideration when selecting a method for management zone classification is the degree of specificity desired. Are assigned zones applicable to only one field, or are they consistent among fields? Can soil pa-

Table 3. Comparison of wheat crop yield variances and standard errors within shallow apparent electrical conductivity $\left(\right.$ EC $\left._{\mathrm{SH}}\right)$ management zones (0-30 cm depth of measurement) classified using equal-size and unsupervised methods.

\begin{tabular}{|c|c|c|c|c|c|c|c|c|}
\hline & \multicolumn{4}{|c|}{1999} & \multicolumn{4}{|c|}{2000} \\
\hline & \multicolumn{2}{|c|}{ Field 5} & \multicolumn{2}{|c|}{ Field 8} & \multicolumn{2}{|c|}{ Field 1} & \multicolumn{2}{|c|}{ Field 4} \\
\hline & Equal size & Unsupervised & Equal size & Unsupervised & Equal size & Unsupervised & Equal size & Unsupervised \\
\hline \multicolumn{9}{|l|}{ EC $_{\text {SH }}$ zone } \\
\hline Low, $\mathrm{kg} \mathrm{ha}^{-1}$ & 29.6 & 40.8 & 37.6 & 28.9 & 18.1 & 17.6 & 15.9 & 26.1 \\
\hline Medium low, $\mathrm{kg} \mathrm{ha}^{-1}$ & 29.6 & 22.2 & 37.7 & 28.2 & 18.1 & 13.3 & 15.9 & 10.2 \\
\hline Medium high, kg ha ${ }^{-1}$ & 29.6 & 25.6 & 37.7 & 48.1 & 18.1 & 19.6 & 15.9 & 17.0 \\
\hline High, $\mathrm{kg} \mathrm{ha}^{-1}$ & 29.6 & 40.2 & 37.7 & 128.2 & 18.1 & 34.1 & 15.9 & 29.1 \\
\hline \multicolumn{9}{|l|}{ Percentage of whole-field } \\
\hline yield variance, $\% \dagger$ & 0.91 & 0.86 & 0.85 & 0.82 & 0.97 & 0.96 & 0.92 & 0.92 \\
\hline$F$ value $\ddagger$ & 59.1 & 60.3 & 115.1 & 150.6 & 32.4 & 45.0 & 99.8 & 90.4 \\
\hline
\end{tabular}

$\dagger$ Within-zone variance expressed as a percentage of yield variance for the whole field (one management zone).

$\uparrow$ Significant at the 0.0001 probability level. 
$\mathrm{EC}_{\mathrm{SH}}$ Zones

(Unsupervised Classification)
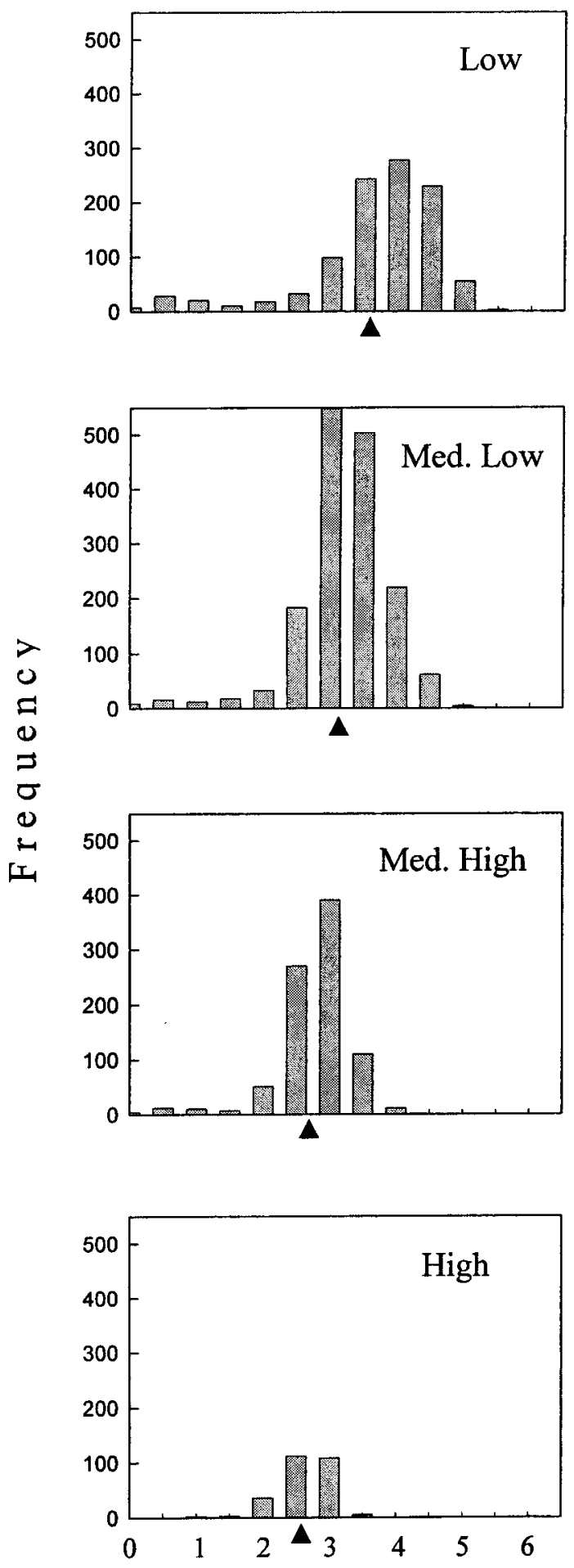

$\mathrm{EC}_{\mathrm{SH}}$ Zones

(Equal-Size Classification)
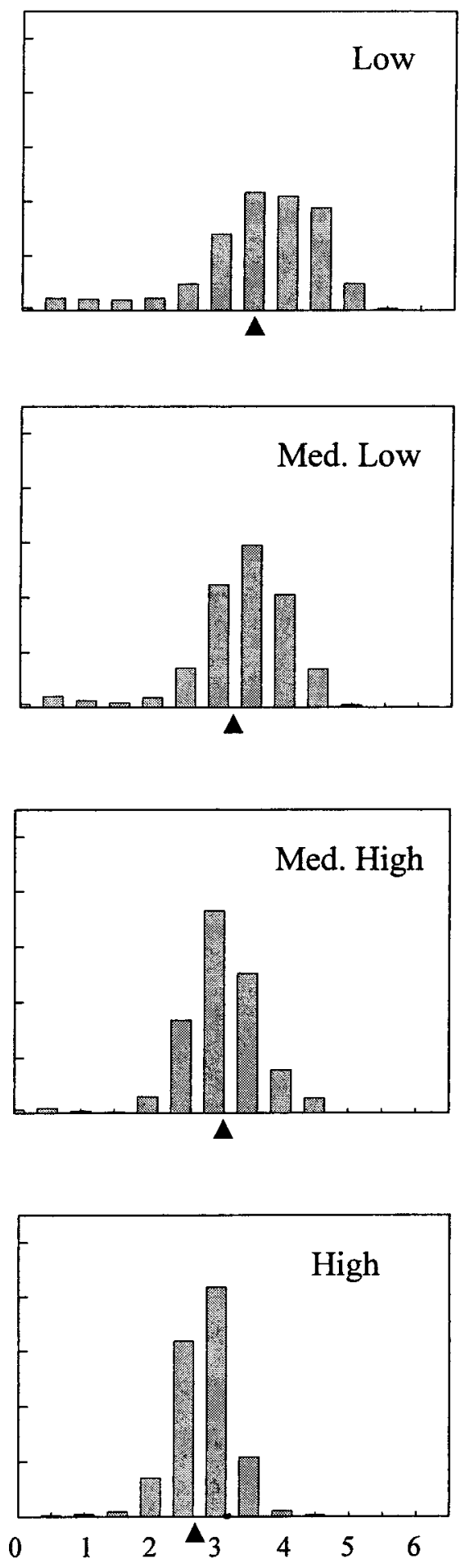

Wheat Yield $\left(\mathrm{Mg} \mathrm{ha}^{-1}\right)$

Fig. 5. Wheat yield frequency distributions for shallow (approximately $\mathbf{0}-30 \mathrm{~cm}$ depth of $\mathrm{EC}_{\mathrm{a}}$ measurement) apparent electrical conductivity classes with unsupervised and equal-size classification methods. The black arrows indicate mean yield within $\mathbf{E C}_{\mathrm{a}}$ classes. 
rameters in management zones within one field be inferred from soil test data results collected from the same zone in another field? The answers to these questions are economically significant and will affect the likelihood of SSM acceptance.

The $\mathrm{EC}_{\mathrm{SH}}$ map collected from the experimental site used in this study documents the variability of $\mathrm{EC}_{\mathrm{SH}}$ among fields (Fig. 1). Measured $\mathrm{EC}_{\mathrm{SH}}$ is a reflection of both historic and recent management in each field. For example, the $\mathrm{V}$-shaped patterns in each of the four corner fields are believed to be the result of around-andaround plowing of the east and west half sections of the site in the 1930s. Recent management history can be visually discerned by differences in the gray-scale map (differences in the magnitude of $\mathrm{EC}_{\mathrm{SH}}$ ) among fields. These differences likely reflect variations in soil water and nutrient status due to uptake by the previous year's crop. For this reason, the application of equal-range classification to each field would preclude the association of $\mathrm{EC}_{\mathrm{SH}}$ zones across field boundaries. Conversely, the $\mathrm{EC}_{\mathrm{SH}}$ map classified by the unsupervised method (Fig. 3) shows a reasonable degree of continuity among $\mathrm{EC}_{\mathrm{SH}}$ zones in adjacent fields, indicating some normalization of measured $\mathrm{EC}_{\mathrm{SH}}$.

For cropping systems using multiple-year rotations, such as the one studied at this experimental site, several years fall between times when a given crop is grown in a given field. This factor, in addition to climatic variability among years, requires the collection of data over several rotations (at least 10 or $12 \mathrm{yr}$ ) to build databases for the SSM of specific crops grown within individual fields. The use of unsupervised classification may allow data collected in multiple fields to be combined for extrapolation to many sites within and across farms.

\section{Implications of Wheat Yield-Shallow Apparent Electrical Conductivity Relationships for Site-Specific Management}

The $\mathrm{EC}_{\mathrm{a}}$-yield relationships identified in this paper, coupled with $\mathrm{EC}_{\mathrm{a}}-$ soil attribute correlations identified in previous experiments (Johnson et al., 2001), provide information essential to the application of SSM in this semiarid cropping system. Effective SSM requires management zones that function: (i) to delineate variations in soil nutrient status and production potential; (ii) as a framework for metering inputs of fertilizer, pesticide, and seed; and (iii) as a basis for identifying yield goals or variations in yield potential across a field.

For a classification system to be effective, it should divide a field into zones delineating the same or similar yield-limiting factors (Lark and Stafford, 1997). Previous experiments at the Farm-Scale Intensive Cropping Study site reveal that management zones based on the unsupervised classification of $\mathrm{EC}_{\mathrm{SH}}$ effectively delineate soil characteristics related to productivity. Soil organic matter, total $\mathrm{C}$ and $\mathrm{N}$, extractable $\mathrm{P}$, water content, and microbial biomass were negatively correlated with $\mathrm{EC}_{\mathrm{SH}}$ and significantly different among $\mathrm{EC}_{\mathrm{SH}}$ zones. Because these zones partition both soil nutrients, $\mathrm{N}$ and $\mathrm{P}$, and other soil characteristics related to nutrient and herbi- cide availability and production potential, they fulfill the first requirement for SSM, a useful basis for soil sampling to assess residual nutrients and soil attributes affecting herbicide efficacy. Second, the strong $\mathrm{EC}_{\mathrm{SH}^{-}}$ yield-soil attribute relationships documented in this study support the employment of $\mathrm{EC}_{\mathrm{SH}}$-based management zones as a framework for metering fertilizer, pesticide, and seed inputs.

Yield response curves can be used as a means to identify maximum crop yields, also known as the boundary line (Webb, 1972), by regressing yield against $\mathrm{EC}_{\mathrm{a}}$. Kitchen et al. (1999) used this type of boundary-line analysis to estimate the magnitude of yield suppression for various crops given different weather and soil conditions; however, they stopped short of suggesting its use for yield goal setting in SSM. This is because $\mathrm{EC}_{\mathrm{a}}-$ yield relationships were highly variable for the claypan soils evaluated in north-central Missouri. Depending on the crop, weather conditions, and soil characteristics, yields increased with increasing $\mathrm{EC}_{\mathrm{a}}$, decreased with increasing $\mathrm{EC}_{\mathrm{a}}$, peaked at midrange values of $\mathrm{EC}_{\mathrm{a}}$, or showed no relationship to $\mathrm{EC}_{\mathrm{a}}$.

Although only 2 yr of data were evaluated, the strong and consistent negative correlations between $\mathrm{EC}_{\mathrm{SH}}$ and wheat yields and positive correlations between $\mathrm{EC}_{\mathrm{DP}}$ and yields of both corn and wheat support greater potential application for boundary-line analyses in this dryland cropping system. Yield data collected in a field in an above-average year may serve as an indicator of maximum potential yield, for that crop in that field, when expressed as a function of $\mathrm{EC}_{\mathrm{a}}$. Given the $2 \mathrm{yr}$ of available data for wheat, the regression of 1999 wheat yields against $\mathrm{EC}_{\mathrm{SH}}$ best portrays within-field wheat yield variability and yield potential (Fig. 6A). Data from the two winter wheat fields in 1999 were combined for this analysis to increase the database size for future SSM application to the entire Farm-Scale Intensive Cropping Study site and potentially to nearby fields of similar soil type and topography. In highly heterogeneous soils, it may be important to collect yield data from specific fields for application to only those fields.

Figure $6 \mathrm{~A}$ illustrates that $\mathrm{EC}_{\mathrm{SH}}$ is yield limiting or more appropriately that soil characteristics integrated by $\mathrm{EC}_{\mathrm{SH}}$ and other soil properties with which they are correlated are yield limiting. As $\mathrm{EC}_{\mathrm{SH}}$ increases, mean and maximum wheat yields decrease. The regression line, defined as data falling at the 90th percentile of yield frequency for each 0.01 increment of $\mathrm{EC}_{\mathrm{SH}}$, indicates maximum yield at various levels of $\mathrm{EC}_{\mathrm{SH}}$ (Fig. 6B). Even with the inclusion of infrequently occurring high- and low-end $\mathrm{EC}_{\mathrm{SH}}$ data, the points are reasonably linear $\left(r^{2}=0.77\right)$. A line, so defined, can be used to identify maximum yield goals for site-specific nutrient determination within $\mathrm{EC}_{\mathrm{SH}^{-}}$-delineated management zones. Nutrient inputs can be based on maximum potential yield within $\mathrm{EC}_{\mathrm{SH}}$ class or a percentage thereof. The economic and ecological implications of fertilizer overapplication must be carefully considered. Nutrient rates based on yield goals short of maximum may be most appropriate in areas where precipitation inputs are rarely sufficient to achieve maximum yield. 

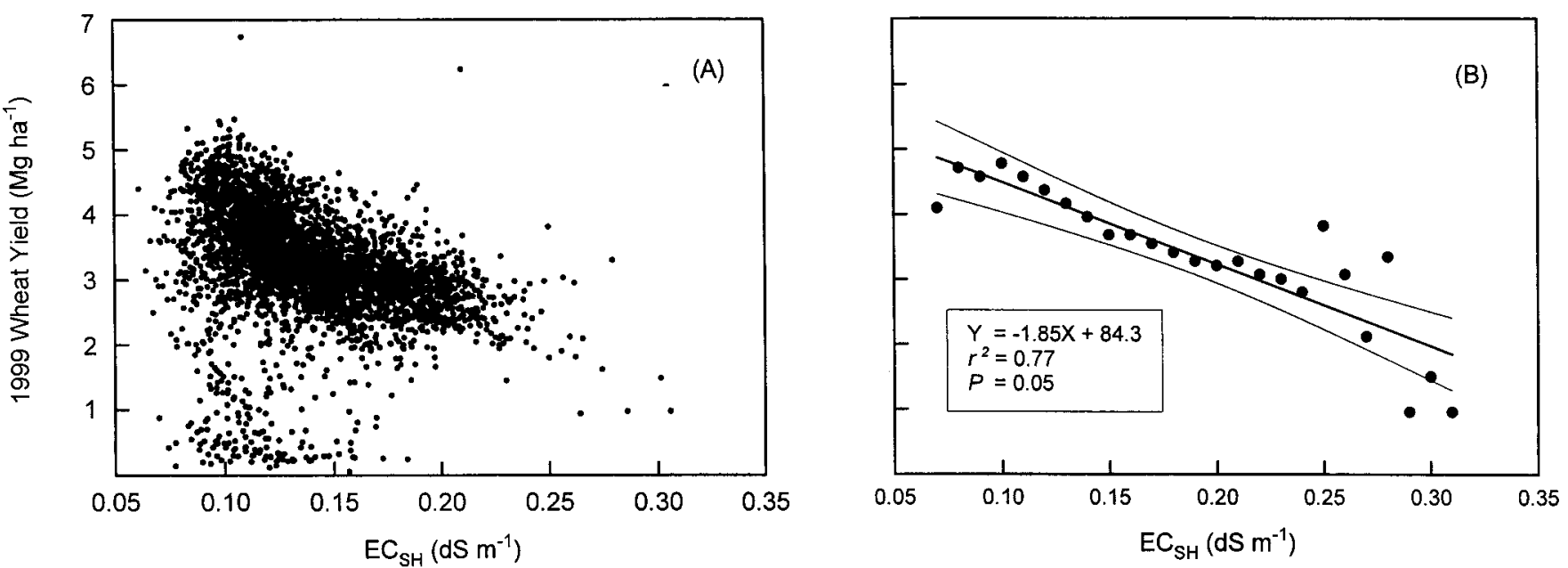

Fig. 6. A) Scatter plot of 1999 winter-wheat yield as a function of shallow (approximately 0-30 cm depth of measurement) apparent electrical conductivity. B) Potential winter wheat yield as a function of shallow apparent electrical conductivity.

\section{CONCLUSIONS}

The success of SSM relies on the creation of appropriate databases to describe spatial variability in past crop performance as a basis for future management decisions to improve economic and ecological outcomes. The exclusive use of $\mathrm{EC}_{\mathrm{a}}$ maps to explain yield variability is not effective, a fact poignantly illustrated by the lack of consistent relationships between corn yield and $\mathrm{EC}_{\mathrm{SH}}$ management zones in this study. This is because the soil factors controlling measured $\mathrm{EC}_{\mathrm{a}}$ may or may not delineate yield-limiting factors; furthermore, weather interactions may alter soil-yield relationships. Similar limitations exist for yield maps. While yield maps are the most realistic integrators of all factors driving yield, they encompass both management-affected (soil-based) and noncontrollable (climate and management) factors. This makes it difficult, if not impossible, to isolate and quantify those factors in yield heterogeneity that can be managed.

However, complementary data layers including an $\mathrm{EC}_{\mathrm{SH}}$-classified map, ground-truth soil test information, and accumulated yield maps appear to address both actual yield and intrinsic soil productivity factors essential to establishing appropriate management zones for the SSM of winter wheat in this semiarid system. Weather influences on crop yield variability tend to be relatively straightforward in semiarid systems where yield variability largely reflects varying degrees of drought stress. For this reason, soil-yield-EC $\mathrm{E}_{\mathrm{a}}$ relationships may be a more stable across years than is true for areas receiving higher rates of precipitation.

Comparison of winter wheat yields and $\mathrm{EC}_{\mathrm{a}}$ showed strong correlations between yield and both $\mathrm{EC}_{\mathrm{SH}}$ and $\mathrm{EC}_{\mathrm{DP}}$ measurement depths in the average and aboveaverage-yielding years encountered in this study. Yields were negatively correlated with $\mathrm{EC}_{\mathrm{SH}}$ and positively correlated with $\mathrm{EC}_{\mathrm{DP}}$. Zone treatments based on $\mathrm{EC}_{\mathrm{SH}}$ showed better yield discrimination than those based on $\mathrm{EC}_{\mathrm{DP}}$. Although $\mathrm{EC}_{\mathrm{a}}$-yield relationships were not evalu- ated for a year with below-average yields, winter wheat yields tend to be reasonably consistent in the central Great Plains when wheat follows a fallow year. Field maps separated into management zones based on unsupervised $\mathrm{EC}_{\mathrm{SH}}$ classification showed slight improvement in zone partitioning (decreased within-zone variance) over equal-size classification. Thus, the unsupervised classification of $\mathrm{EC}_{\mathrm{SH}}$ appears to be the best basis for management zone identification in winter wheat. Future research is required to determine to what degree these results can be generalized to a regional scale.

Strong correlations among $\mathrm{EC}_{\mathrm{SH}}$, soil properties, and wheat yields indicate that $\mathrm{EC}_{\mathrm{SH}_{\mathrm{H}}}$-delineated management zones provide an excellent framework for SSM of dryland winter wheat. Management zones based on the unsupervised classification of $\mathrm{EC}_{\mathrm{SH}}$ serve three functions essential to SSM. They provide: (i) a basis for soil sampling to assess nutrient levels and soil attributes affecting herbicide efficacy; (ii) a means to calculate nutrient inputs by using boundary-line analyses between $\mathrm{EC}_{\mathrm{SH}}$ and wheat yield to identify yield goals (variation in maximum yield potential across a field); and (iii) a prescription map for metering fertilizer, pesticide, and seed inputs. The first two functions are essential for determining fertilizer, herbicide, and seeding rates within management zones while the last delineates the zones to which they will be applied.

Similar potential exists for SSM of corn. Within-zone corn yield means for the below-average and low-yielding years studied showed no consistent relationship with $\mathrm{EC}_{\mathrm{SH}}$ but strong positive correlation with $\mathrm{EC}_{\mathrm{DP}}$. Because corn yields are highly variable in the region studied, even if strong correlations are found between $\mathrm{EC}_{\mathrm{SH}}$ and corn yields in high-yielding years, $\mathrm{EC}_{\mathrm{DP}}$ may offer a more realistic basis for the establishment of SSM zones for corn. Further research is required to identify the soil factors driving measured $\mathrm{EC}_{\mathrm{DP}}$ and characterize soils falling within $\mathrm{EC}_{\mathrm{DP}}$-based management zones. The con- 
tinued collection of winter wheat and corn yield maps from this study site over a number of low-, average-, and high-yielding years, and the evaluation of these data in conjunction with $\mathrm{EC}_{\mathrm{SH}}$ and $\mathrm{EC}_{\mathrm{DP}}$, will improve our ability to establish appropriate management zones for both wheat and corn in this semiarid setting.

\section{ACKNOWLEDGMENTS}

We thank Russ and Matt Johnson, landowners and managers of the experimental site, and Maribeth Milner, Michael Schlemmer, and Aaron Schepers for excellent technical assistance.

\section{REFERENCES}

Bouma, J., and P.A. Finke. 1993. Origin and nature of soil resource variability. p. 3-14. In P.C. Robert et al. (ed.) Proc. Soil Specific Crop Manage.: A Workshop on Res. and Dev. Issues. 14-16 Apr. 1992. ASA, Madison, WI

Cambardella, C.A., and D.L. Karlen. 1999. Spatial analysis of soil fertility parameters. J. Precis. Agric. 1:5-14.

Castelnuovo, R. 1995. Environmental concerns driving site-specific management in agriculture. p. 867-880. In P.C. Robert et al. (ed.) Proc. Int. Conf. Site-Specific Manage. for Agric. Syst., 2nd, Minneapolis, MN. 27-30 Mar. 1994. ASA, CSSA, and SSSA, Madison, WI.

Doolittle, J.A., K.A. Sudduth, N.R. Kitchen, and S.J. Indorante. 1994 Estimating depths to claypans using electromagnetic induction methods. J. Soil Water Conserv. 49:572-575.

Eliason, M., D. Heaney, T. Goddard, M. Green, C. McKenzie, D. Penney, H. Gehue, G. Lachapelle, and M.E. Cannon. 1995. Yield measurement and field mapping with an integrated GPS system. p. 49-58. In P.C. Robert et al. (ed.) Proc. Int. Conf. Site-Specific Manage. for Agric. Syst., 2nd, Minneapolis, MN. 27-30 Mar. 1994. ASA, CSSA, and SSSA, Madison, WI.

ERDAS. 1997. ERDAS field guide. p. 225-232. ERDAS, Atlanta, GA.

Fleming, K.L., D.G. Westfall, D.W. Wiens, L.E. Rothe, J.E. Cipra, and D.F. Heerman. 1999. Evaluating farmer developed management zone maps for precision farming. p. 335-343. In P.C. Robert et al. (ed.) Proc. Int. Conf. Precision Agric., 4th, St. Paul, MN. 19-22 July 1998. ASA, CSSA, and SSSA, Madison WI.

Fraisse, C.W., K.A. Sudduth, and N.R. Kitchen. 2001. Delineation of site-specific management zones by unsupervised classification of topographic attributes and soil electrical conductivity. Trans. ASAE 44(1):155-166.

Griffith, D. 1995. Incorporating economic analysis into on-farm GIS p. 723-729. In P.C. Robert et al. (ed.) Proc. Int. Conf. Site-Specific Manage. for Agric. Syst., 2nd, Minneapolis, MN. 27-30 Mar. 1994. ASA, CSSA, and SSSA, Madison, WI.

Jaynes, D.B., T.S. Colvin, and J. Ambuel. 1993. Soil type and crop yield determinations from ground conductivity surveys. Paper 933552. Am. Soc. of Agric. Eng., St. Joseph, MI.

Jaynes, D.B., T.S. Colvin, and J. Ambuel. 1995a. Yield mapping by electromagnetic induction. p. 383-394. In P.C. Robert et al. (ed.) Proc. Int. Conf. Site-Specific Manage. for Agric. Syst., 2nd, Minneapolis, MN. 27-30 Mar. 1994. ASA, CSSA, and SSSA, Madison, WI

Jaynes, D.B., J.M. Novak, T.B. Moorman, and C.A. Cambardella. 1995b. Estimating herbicide partition coefficients from electromagnetic induction measurements. J. Environ. Qual. 24:36-41.

Jenny, H. 1941. Factors of soil formation: A system of quantitative pedogenesis. McGraw-Hill, New York.

Johnson, C.K., J.W. Doran, H.R. Duke, B.J. Wienhold, K.M. Eskridge, and J.F. Shanahan. 2001. Field-scale electrical conductivity mapping for delineating soil condition. Soil Sci. Soc. Am. J. 65:1829-1837.

Kitchen, N.R., K.A. Sudduth, and S.T. Drummond. 1999. Soil electrical conductivity as a crop productivity measure for claypan soils. J. Prod. Agric. 12:607-617.

Kravchenko, A.N., D.G. Bullock, and H.F. Reetz. 2000. Correlation of corn and soybean grain yield with topography and soil properties. Agron. J. 92:75-83.

Lark, R.M. 1997. Variation in soil conditions and crop performance. p. 127-135. In J.V. Stafford (ed.) Precision agriculture-'97. Proc. Eur. Conf. Precision Agric., 1st, Warwick Univ. Conf. Cent., UK. 7-10 Sept. 1997. BIOS Sci. Publ., Oxford, UK.

Lark, R.M., and J.V. Stafford. 1997. Classification as a first step in the interpretation of temporal and spatial variation of crop yield. Ann. Appl. Biol. 130:111-121.

Larson, W.E., J.A. Lamb, B.R. Khakural, R.B. Ferguson, and G.W. Rehm. 1997. Potential of site-specific management for non-point environmental protection. p. 337-367. In F.J. Pierce and E.J. Sadler (ed.) The state of site specific management for agriculture. ASA, CSSA, and SSSA, Madison, WI.

Larson, W.E., and P.C. Robert. 1991. Farming by soil. p. 103-112. In R. Lal and F.J. Pierce (ed.) Soil management for sustainability. Soil and Water Conserv. Soc., Ankeny, IA.

Lund, E.D., D. Christy, and P.E. Drummond. 1999. Applying soil electrical conductivity technology to precision agriculture. p. 10891100. In P.C. Robert et al. (ed.) Proc. Int. Conf. Precision Agric., 4th, St. Paul, MN. 19-22 July 1998. ASA, CSSA, and SSSA, Madison WI.

Malhi, S.S., M. Nyborg, J.T. Harapiak, and N.A. Flore. 1991. Acidification of soil in Alberta by nitrogen fertilizers applied to bromegrass. Dev. Plant Soil Sci. 45:547-553.

McCann, B.L., D.J. Pennock, C. van Kessel, and F.L. Walley. 1996 The development of management units for site-specific farming. p. 295-302. In P.C. Robert et al. (ed.) Proc. Int. Conf. Precision Agric., 3rd, St. Paul, MN. 23-26 June 1996. ASA, CSSA, and SSSA, Madison WI.

McNeill, J.D. 1980. Electrical conductivity of soils and rocks. Tech. Note TN-5. Geonics, Mississauga, ON, Canada.

Mulla, D.J. 1991. Using geostatistics and GIS to manage spatial patterns in soil fertility. p. 336-345. In G. Kranzler (ed.) Proc. Automated Agric. 21st Century, Chicago, Il. 16-17 Dec. 1991. ASAE, St. Joseph, MI

Nielsen, D.C. 1996. Estimating corn yields from precipitation records. Conserv. Tillage Fact Sheet 2-96. USDA-ARS, USDA-NRCS, and Colorado Conserv. Tillage Assoc., Akron, CO.

Reetz, H.F., and P.E. Fixen. 1995. Economic analysis of site-specific nutrient management systems. p. 743-752. In P.C. Robert et al. (ed.) Proc. Int. Conf. Site-Specific Manage. for Agric. Syst., 2nd, Minneapolis, MN. 27-30 Mar. 1994. ASA, CSSA, and SSSA, Madison, WI.

Rhoades, J.D., N.A. Manteghi, P.J. Shouse, and W.J. Alves. 1989. Soil electrical conductivity and soil salinity: New formulations and calibrations. Soil Sci. Soc. Am. J. 53:433-439.

Robert, P.C. 1989. Land evaluation at farm level using soil survey information systems. p. 299-311. In J. Bouma et al. (ed.) Land qualities in space and time. Proc. ISSS Symp., Wageningen, the Netherlands. 22-26 Aug. 1988. Purdoc, Wageningen, the Netherlands.

Sadler, E.J., P.J. Bauer, and W.J. Busscher. 1995. Spatial corn yield during drought in the SE Coastal Plain. p. 365-381. In P.C. Robert et al. (ed.) Proc. Int. Conf. Precision Agric., 3rd, St. Paul, MN 23-26 June 1996. ASA, CSSA, and SSSA, Madison WI.

SAS Institute. 1997. SAS/STAT software: Changes and enhancements through release 6.12. SAS Inst., Cary, NC.

Stafford, J.V., R.M. Lark, and H.C. Bolam. 1999. Using yield maps to regionalize fields into potential management units. p. 225-237. In P.C. Robert et al. (ed.) Proc. Int. Conf. Precision Agric., 4th, St. Paul, MN. 19-22 July 1998. ASA, CSSA, and SSSA, Madison WI

Sudduth, K.A., S.T. Drummond, and N.R. Kitchen. 2001. Accuracy issues in electromagnetic induction sensing of soil electrical conductivity for precision agriculture. Comput. Electron. Agric. 31:239-264.

Sudduth, K.A., J.W. Hummel, and S.J. Burrell. 1997. Sensors for sitespecific management. p. 183-210. In F.J. Pierce, P.C. Robert, E.J. Sadler, and S. Searcy (ed.) Proc. Symp. State of Site Specific Manage. for Agric., St. Louis, MO. 31 Oct. 1995. ASA, CSSA, and SSSA, Madison, WI.

Sudduth, K.A., N.R. Kitchen, D.F. Hughes, and S.T. Drummond. 1995. Electromagnetic induction sensing as an indicator of productivity on claypan soils. p. 671-681. In P.C. Robert et al. (ed.) Proc. Int. Conf. Site-Specific Manage. for Agric. Syst., 2nd, Minneapolis, MN. 27-30 Mar. 1994. ASA, CSSA, and SSSA, Madison, WI. 
Tomer, M.D., J.L. Anderson, and J.A. Lamb. 1995. Landscape analysis of soil and crop data using regression. p. 274-284. In P.C. Robert et al. (ed.) Proc. Int. Conf. Site-Specific Manage. for Agric. Syst., 2nd, Minneapolis, MN. 27-30 Mar. 1994. ASA, CSSA, and SSSA, Madison, WI.

Van Uffelen, C.G.R., J. Verhagen, and J. Bouma. 1997. Comparison of simulated crop yield patterns for site-specific management. Agric. Syst. 54:207-222.
Vieira, S.R. 1999. Geostatistical applications in mapping of crop yield and soil properties. p. 365-375. In J.V. Stafford (ed.) Proc. European Conf. Precision Agric., 2nd, Odense Congr. Cent., Denmark. 11-15 July 1999. Sheffield Academic Press, Sheffield, UK.

Wallace, A. 1994. High-precision agriculture is an excellent tool for conservation of natural resources. Commun. Soil Sci. Plant Anal. 25:45-49.

Webb, R.A. 1972. Use of the boundary line in the analysis of biological data. J. Hortic. Sci. 47:309-319. 